\title{
Pola komunikasi dalam mengatasi konflik antar suku Nias dan Batak Desa Tanjung Mas Kampar Kiri
}

\author{
Suhaimi $^{1}$, Darmawati ${ }^{2}$, M.Fahli Zatrahadi ${ }^{3}$, Yurnalis $^{4}$ dan Miftahuddin $^{5}$ \\ ${ }^{12345}$ Univeristas Islam Negeri Sultan Syarif Kasim Riau, Pekanbaru, Indonesia
}

\begin{abstract}
:
A conflict, defined as a clash of interest, derives from incompatible interactions whether individuals or groups in social entities, economic, political, and cultural activities, and in turns, conflict that arises create social instability. The current research objectives are to figure out the conflict that occurs in Tanjung Mas Village and to determine the right communication patterns in resolving existing matters. Conducted through qualitative case study, the chosen location was Tanjung Mas Village, Kampar Kiri Riau, the informants were the village head, the head of the Nias and the Batak tribes. The results obtained in this line of research demonstrated that the most common factors that lead to conflict are economic factor, the Nias people are generally stronger but receive cheaper salary than the Batak, thus an employer would prefer the Nias rather than the Batak, hence it gives way to conflict, another factor is also due to sport. In this regard, conflict resolution stages conducted by the head of the tribes is through mediation.
\end{abstract}

Keyword: Persuasive communication, communication patterns, tribal conflict

\section{PENDAHULUAN}

Indonesia merupakan negara majemuk, yang terdiri dari ragam agama, suku bangsa, adat istiadat, dan bahasa yang saling berbeda, yang memposisikan bangsa Indonesia menjadi negara yang penuh toleransi, bahkan diikat dengan semboyan Bhinneka Tunggal Ika, yang menjadi moto bagi rakyat bangsa Indonesia di lambang negara yaitu Garuda Pancasila (Gesmi, Sos, Si, \& Yun Hendri, 2018). Namun belakangan ini perbedaan suku dan adat ini, tidak lagi disikapi secara dewasa dan lebih mengedepankan rasa intoleransi. Hal ini tentu berimplikasi pada munculnya konflik sosial di masyarakat. Kebanyakan dari konflik yang timbul akan lebih memberikan dampak negative bagi kehidupan bermasyarakat yang mana menimbulkan kerusakan, menciptakan ketidakstabilan dalam tatanan masyarakat, tidak harmonis, tidak memberi rasa aman dan bahkan dari konflik tersebut bisa mengakibatkan korban jiwa didalamnya (Lestari, 2012).

Konflik lahir dari adanya interaksi antara individu ataupun kelompok dalam kehidupan skonomi, social, politik dan budaya (Adi, 2015), yang menjadi tiga pilira untama dalam terbentuknya konflik adalah 
watak psikologis, fenomena politik, dan ekonomi(Affandi, 2004). Kelompok yang mempunyai mempunyai kekuasaan didalamnya akan berusaha sekuat mungkin untuk memperjuangkan kepentingnya, dan kelompok yang tidak mempunyai kekuasaan akan secara paksa untuk memperjuangankan kepentingnya dengan cara yang berbeda, sehingga dari perbedaan tersebut saling bertentangan (Aslati, Silawati, Darmawati, \& Zatrahadi, 2019). Konflik suatu proses dalam melakukan pertentangan dan persaingan, perselisihan, dan perseteruan, dengan cara masing-masing individu atau kelompok berusaha untuk menggagalkan tujuan yang ingin dicapai oleh masingmasing kelompok atau individu. Konflik yang muncul membuat ketidakstabilan didalam tatanan kehidupan masyarakat yang berkonflik (Irwandi \& Chotim, 2017).

Hal ini terjadi di Desa Tanjung Emas Kabupaten Kampar Provinsi Riau. Di Desa ini, Konflik sering terjadi di kalangan masyarakat komunitas suku Batak dengan suku Nias. Kedua suku ini adalah pendatang dari Provinsi Sumatera Utara. Mereka merantau ke desa ini sebagai petani dan bekerja di perkebunan sawit yang ada. Konflik timbul karna fenomena ekonomi yang bersumber pada perebutan lading rezeki (ekonomi) dan didukung oleh persoalan distribusinya, koflik yang terjadi diawali oleh hal yang sepele dan sedehana. Fenomena ekonomi bersumber pada perebutan sumber-sumber ekonomi dan persoalan distribusinya, Konflik yang terjadi biasanya terjadi karena hal sederhana dan sepele seperti prasangka negatif tetapi berhubung menyangkut Ras dan budaya maka rasa simpati antar sesama budaya yang membuat peperangan, tawuran dan dendam antar suku yang menjadikan hal tersebut menjadi bukan lagi hal yang sepele bahkan hingga terjadinya perang antar suk, yang diakibatkan oleh konflik tersebut(Hadi, 2015).

Suku Batak merupakan rumpun suku-suku yang ada di Sumatera Utara (Tarigan \& Dumayanti, 2018). Pada umunya suku batak tidak terdiri dari ama Kristen saja, melaikan terdiri dari ahama islam, Kristen, prosestan, kridten, katolik. Namun ada juga yang masih menganut kepercayaan tradisional. Sedangkan suku Nias merupakan masyarakat yang hidup dalam lingkungan adat dan kebudayaan yang masih tinggi (Harefa, 2013). Tujuan penelitian untuk memetakan konflik yang terjadi di Desa Tanjung Mas dan menentukan pola komunikasi yang tepat dalam mengatasi konflik yang ada, Bagaimana pola komunikasi dalam mengatasi konflik suku Batak dan suku Nias di Desa Tanjung Harapan kecamapat Kampar Kiri Hilir Kabupaten Kampar..

\section{METODE}

Penelitian ini menggunakan metode penelitian kualitatif yang bersifat studi kasus (case study) dalam penelitian studi kasus unit yang diteliti lebih sempit tetapi mendalam.(Yusuf, 2010) Adapun tahapan di dalam penelitian ini: 1) merumuskan tujuan yang jelas, 2) menetapkan metode yang akan digunakan, 3) mengumpulkan data, 4) laporan. Lokasi penelitian terletak di Desa Tanjung Mas Kampar Kiri Riau yang mayoritas masyarakatnya dari suku Batak dan Nias, yang mempunyai penghasilan utama sebagai tukang takik getah atau potong getah dan juga sebagai dodos sawit. Adapaun informan dalam pengumpulan data peneltian ini ialah kepala suku Batak, kepala suku Nias, dan kepala Desa.

Teknik pengumpulan data terdiri dari data primer dan data sekunder, untuk mendapatkan dua data tersebut, maka penelti menggunakan tiga metode yaitu: 1. Wawancara, 2. Pengamatan (observasi), 3. Studi dokumentasi. Setelah data terkumpul dengan menggunakan tiga metode, maka untuk menjamin keabsahan data yang terkumpul peneliti mengacu pada penggunaan standar keabsahan data menurut sanafiah yaitu: 1. Kepercayaan (Credibility), 2. Keteralihan (Tranferability), 3. Dapat Dipercaya (Dependability), 4. Penegasan atau Kepastian (Conformability). Teknik analisis data berpedoman pada model Spradley yang disesuaikan dengan kebutuhan yaitu: menentukan situasi social, melakukan pengamatan lapangan, melakukan analisa kawasan, dan terakhir menulis lapora. Menulis laporan dibuat dalam bentuk tulisan etnographi (Lubis, 2017).

\section{HASIL DAN PEMBAHASAN}

Pola komunikasi mengatasi konflik antara suku Batak dan suku Nias ialah dengan cara mengetahui terlebih dahulu factor penyebab konflik yang terjadi. Batak dan Nias yang mempunyai kebudayaan yang berbeda-beda sehingga dari perbedaan tersebut sering kali menjadi dasar utama terjadinya suatu konflik pada masyarakat yang berbeda social dan budaya. Setiap suku memilki latar belakang, kebiasaan, gaya hidup yang berbeda tentunya ini memicu munculnya konflik. Konflik yang terjadi seperti dibidang olahraga, setiap momen olah raga yang diadakan pada Desa tersebut pasti berujung perkelahian oleh karena itu setiap kepala desa memutuskan untuk menghilangkan aktifitas pertandingan antar suku untuk mengecilkan kemungkinan konflik antar suku.

Konflik lain juga disebabkan oleh faktor ekonomi, orang suku Batak yang mata pencariannyaa lebih menjadi petani atau beladang sedangkan suku Nias mata pencariannya lebih cenderung bekerja di pabrik sawit 
karna toke pabrik kelapa sawit lebih suka menggunakan jasa orang nias karna orang nias yang tidak banyak menuntut, lincah, dan upah yang diberikan tidak terlalu besar dari pada menggunakan jasa orang batak sehinggga orang batak merasa tertinggal dan merasa dikalahkan dalam kegiatan perekonomian yang ada. Konflik yang awalnya dipicu oleh permasalahan yang sederhana namun kelamaan menjadi besar dan kerusuhan yang diidentifikasi oleh adanya benturan budaya etnis batak dan etnis nias, dan ditambah lagi dengan lemahnya hukum dan adanya tindak kekerasan yang terjadi, benutran etnis budaya ini disebabkan oleh kesombongan dan tidak ada kepedulian etnis terhadap peraturan hukum adat yang telah di buat.

Untuk itu dalam penyelesaian konflik yang dipelukkan ialah memberikan semangat damai pada kedua belah pihak, berkomunikasi dengan tidak emosional atau tidak melakukan kekerasan, memberikan rasa damai dan aman. Dengan membuat aturan yang disepakati bersama, menegakkan hukum di desa tersebut dengan hukum itu berlaku untuk seluruh masyarakat tanpa membedakan antar suku. System atau mekanisme yang lain untuk mengendalikan konflik di dalam masyarakat itu: melakukan Konsiliasi, mediasi, arbitrasi yang dilakukan oleh kepala desa, dan masing-masing kepala suku.

Apabila konflik telah diselesaikan maka konflik tidak akan berkelanjutan, Tidak ada pengelompokan antar suku, tidak ada kesenjangan antara suku pendatang dan suku yang ada didesa ini, menciptakan kerukunan didalam masyarakat. Kerukunan didalam masyarakat dapat diartikan sebagai situasi yang bebas konflik tanpa adanya pertikaian, dalam menciptakan kerukunan didalam masyrakat merupakan kewajiban bagi setiap individu didalamnya, sehingga nilai dan norma-norma yang harus diterapkan oleh setiap elemen masyarakat sejak dini.

Mengingat begitu beragamnya latar belakang dan tingkat sosial masyarakat, maka persoalan hak dan kewajiban senantiasa muncul menjadi konflik sosial yang berkepanjangan dan terjadi di desa Tanjung Emas, dengan demikian juga terjadi pelanggaran hak hidup damai dan sejahtera dalam bermasyarakat.

Setiap suku memilki latar belakang, kebiasaan, gaya hidup yang berbeda tentunya ini memicu munculnya konflik, Konflik yang terjadi seperti dibidang olahrga, setiap momen olah raga yang diadakan pada Desa tersebut pasti berujung perkelahian oleh karena itu setiap kepala desa memutuskan untuk menghilangkan aktifitas pertandingan antar suku untuk mengecilkan kemungkinan konflik antar suku. Konflik terjadi juga dikarenakan faktor ekonomi, hal ini terutama pada dua suku yakni suku batak dan nias, biasanya orang nias lebih kuat dan lebih murah gajinya sehingga para toke lebih suka dengan tenaga mereka, suku batak tidak menerima hal ini dan terjadilah konflik karena gaji orang batak lebih besar sehingga toke tentu lebih memilih orang nias ditambahlagi suku nias punya kecenderungan tertutup tidak banyak menuntut sehingga lebih cenderung disukai oleh pengusaha, hal ini lah yang menjadi sumber utama konflik sehingga perlu diselesaikan dengan semua pihak untuk mendamaikan dua suku.

Sosial masyarakat, nias lebih suka bergabung dengan sesama nias cenderung tidak mau bergaul sehingga mereka kurang mampu berbahasa Indonesia hal ini mengakibatkan mereka kurang bisa bergaul dengan masyarakat yang lain, hal ini juga yang menjadi masalah karena ketidaksatuan didalam berbahasa, sehingga sering terjadi permasalahan karena salah memahami dalam beromunikasi, yang disebabkan rendahnya pendidikan masyarakat suku nias. Kehidupan bermasyarakat Suku Nias dan Batak sering kali terjadi permasalahan yang disebabkan oleh ketidakpahaman budaya oleh kedua belah pihak. Sulitnya untuk menyesuaikan diri dan sering merasa ketidakcocokan di antara kedua etnid ini yang menyebabkan mudahnya terjadi konflik antar mereka, ditambah lagi dengan adanya rasa kecurigaan dan kebencian yang membuat hubungan keduanya semakin tidak harmonis.

Masyarakat batak juga memiliki ciri khas dalam mencari nafkah atau dalam memenuhi kebutuhan ekonominya yaitu dengan menjadi seorang petani atau berladang. Sedangkan suku Nias mata pencariannya kebanyakan bekerja di pabrik sawit tentu penghasilanya lebih besar. Pabrik kelapa sawit yang pekerjanya dominan pada suku nias daripada orang suku Batak. Hal ini yang menyebabkan terjadinya kecemburuan social karna merasa terpinggirkan dan tertinggal dari kegiatan perekonomian sehingga persoalan dan konflik itu akan tercipta dengan mudah.

Konflik yang dipicu oleh persoalan yang sepele atau sederhana, namun menjadi kerusuhan dan didentifikasikan sebagai timbul awalnya konflik itu dikarenakan adanya benturan etnis dari masing-masing suku. Dengan lemahnya penegakan hukum ditatanan masyarakat, tindak kekerasan yang terjadi, yang menyebabakna benturan kebudayaan ini semakain besar dan tingkat kesombongan dan ketidakpedulian terhadap hukum adat dan budaya local akan semakain menjadi luas. 
Darmawati, et al.

Dibidang olahraga, penyebab konflik yang terjadi akibat kesalah pahaman antara pemain, wasit dan penonton atau sporter antara tim seperti tidak mematuhi aturan yang telah disepakati. Salah satu tim memantah aturan merasa wasit tidak adil dan sebagainya. Dalam permainan pasti ada kalah menang akan tetapi didalam tim ini apabila salah satu sudah mendapatkan scor pemain tidak bermain secara aturan, bermain secara kasar dan mengakibatkan tim lain merasa tidak dihargai dan mengakibatkan konflik terjadi. Didalam komunikasi, sering terjadinya diskomunikasi yang mengkibatkan kesalahpahaman antar suku.

Dibidang olahraga pada awalnya konflik diselesaikan oleh wasit akan tetapi pemain serta sporter antar tim tidak menerima dan diselesaikan oleh pihak desa seperti kades, sekdes dan toko masyarakat yang dihargai di desa ini. Apabila konflik tetap berlanjut maka pihak panitia mengundang kepala suku antar tim, toko masyarakat dan pihak desa menyelesaikan serta bermusyawarah bersama agar masalah tidak berkelanjutan. Perbedaan pendapat yang terjadi sebenarnya itu meupakan hal yang alami, namun akan menjadi tidak alami atau tidak wajar apabila tidak bisa dikendalikan, yang akan berubah menjadi pemicu adanya kekerasan yang merusak kedamaian kedua belah pihak dan lingkungan sekitarnya. Untuk itu diperlukannya metode atau cara yang damai kepada kedua belah pihak, jika konflik yang memnyebabkan tindakan kekerasan ini bisa diselesaikan dengan baik tanpa membalas dengan tindakan kekerasanmaka tatanan masyarakat didalamnya akan merasakan kedamaian dan keamanan atas cara yang digunakan tersebut.

Untuk menghilangkan konflik tidak mudah, karna untuk menghilangn suatu konflik yang terjadi dengan bersamaan hilangnya masyarakat itu sendiri. Oleh karna yang dapat kita lakukan ialah dengan mengendalikan konflik tersebut tidak menjadi besar dan berubah menjadi tindakan kekerasan. Membuat aturan serta mensepekati bersama, mengatasi agar tidak adanya pengelompokan antar suku. Menegakkan hukum di desa tanjung mas yang berlaku untuk seluruh masyarakat tampa membedakan antar suku.

Pada umumnya masyarakat memiliki sistem atau mekanisme untuk mengendalikan konflik di dalam masyarakat itu sendiri, diantaranya : Konsiliasi diartikan sebagai bentuk pengaturan konflik yang dilakukan oleh lembaga-lembaga tertentu yang terlibat untuk memungkinkan mengadakan forum diskusi untuk mengambil kebijakan dan keputusan yang adil diantara pihak-pihak yang bertikai. Kemudian, dilakukan tindakan mediasi untuk memperkecil dan memperjelas kembali pengendalian konflik yang dilakukan menggunakan orang ketiga bertugas sebagai mediator. Terakhir, melakukan tindakan arbitrasi dilakukan apabila kedua belah pihak telah setuju dan menyepakati hadirnya pihak ketiga yang akan memberikan keputusan terbaik untuk menyelesaikan konflik.

Metode lain yang bisa digunakan juga dalam menyelesaikan konflik yang terjadi yakni dengan cara memenangkan suatu pihak atas pihak lain. Melakukan kesepakatan atau komrpomi di antara pihak-pihak yang bertikai, sehingga didalam pertandingan tidak ada pihak yang menang dan yang kalah. Terus melakukan Rekonsiliasi antara pihak yang betikai, hal ini bertujuan untuk mengembalikan rasa kepercayaan yang sangat penting dimiliki oleh masing-masing pihak bertikai. Dan saling meminta maag anatar pihak satu dengan pihak yang lain dan membuat kesepakatan untuk tidak berkonflik lagi.

Kepala suku, kades dan toko masyarakat yang dihargai bermusyawarah agar masalah tidak berkelanjutan dan menitik beratkan agar tidak berkelompok-kelompok antar suku. Peran Kepala Desa yang meliputi membuat suatu pola sikap, dan komunikasi. Peran kepala desa juga berarti sebagai serangkain perilaku yang ditunjukkan dalam kehidupan mayarakat dengan harapan lingkungan social masyarakat social dapat berhubungan baik dengan individu social.

Perasanan kepala suku dalam menyelesaikan konflik dengan menjadi hakim perdamaian dilakukan secara adat, dan kepala suku juga bertugas ssebagai seseorang pengambil keputusan adat, yang mana keputusan yang diambil mengikat pada keputusan serta mendipykan kerukunan dalam keluarga masyarakat, dimana setiap perubahan tindakan kepala suku bersadarkan tuntutan 3 sifat yaitu: dapat menjaga kemanan masyarakat sesuku antar suku yang ada dimasyarakat, memelihara kedamaian masyarakat di antara masyarakat sesuku maupun antar suku dan memlihara derajat agama dan kepercayaan masing-masing.

Menciptakan kerukunan dan keharmoisan disalam tatanan masyarakat merupakan kewajiban bagi setiap individu. Oleh karna itu nilai dan norma yang telah dibuat dan disepakati dari awal harus diterapkan dan harus dijalankan dengan sebaik-baiknya dan mulai di tanam sejak dini. Agar ketika terjun dilingkungan masyarakat, linkungan tersebut dapat menerimanya, dengan cara menerapkan nilai norma yang sudah lazim diterapkan. Seperti bersikap baik dan sopan, saling mengahragai dan menghormati sesame indivisu, serta menghindari perkataan kasar yang dapat membuat dan menyinggung hati dan perasaan orang lain. Dengan terciptanya 
kerukunan dalam kehidupan bermasyarakat tentunya akan berdampak positif bagi manusia sebagai makhluk sosial, diantaranya adalah mengciptakan komunikasi yang baik antar sesama demi menghindari munculnya konflik dan pertikaian, membuat suasana kehidupan masyarakat yang nyaman dan harmonis sehingga dapat menumbuhkan individu yang toleran, kehidupan lebih aman dan tentram karena tidak ada ancaman dari pihak lain, membantu memperkokoh hubungan, persatuan dan kesatuan didalam hidup bermasyarakat, mempererat tali persaudaraan dan menghindari perselisihan,

\section{KESIMPULAN}

Agar warga tanjung mas mampu terhindar dari konflik maka perlu membuka komunikasi antar suku dengan tidak ada pengelompokan antar suku, dengan berbaur akan mudah memahami adat istiadat masingmasing suku dan mulai bisa beradaptasi satu sama lain. Dengan demikian akan terhindarlah kesenjangan antara suku pendatang dan suku yang ada di desa. Perlu juga diberikan persamaan upah sesuai kesepakatan antar suku sehingga dengan ini akan memeinimalisir terjadinya konflik dari sector ekonomi.

\section{DAFTAR RUJUKAN}

Adi, D. S. (2015). Pengelolaan potensi konflik antar etnik. Prosiding Seminar Nasional Industrialisasi Madura (SNIRA)." Peluang, Tantangan Dosen Dan Perguruan Tinggi Menghadapi Masyarakar Ekonomi ASEAN 2015, 1-6. Fakultas Teknik Universitas Trunoioyo Madwa.

Affandi. (2004). Akar Konflik Sepanjang Zaman; Elaborasi Pemikiran Ibn Khaldun.

Aslati, A., Silawati, S., Darmawati, D., \& Zatrahadi, M. F. (2019). Sinergi Polri Bersama Masyarakat Di Tanjung Balai Karimun Dalam Mencegah Radikalismedan Pengamalan Hadist Intoleransi. Sosiohumaniora, 21(3).

Gesmi, I., Sos, S., Si, M., \& Yun Hendri, S. H. (2018). Buku Ajar Pendidikan Pancasila. Uwais Inspirasi Indonesia.

Hadi, M. F. Z. (2015). Tasawuf untuk Kesehatan Mental. An-Nida', 40(1), 31-41.

Harefa, A. (2013). Eksistensi "Fondrakõ" Dalam Hukum Adat Nias. Didaktik: Jurnal Ilmiah Pendidikan, Humaniora, Sains, Dan Pembelajarannya, 7(1), 1026-1039.

Irwandi, I., \& Chotim, E. R. (2017). Analisis Konflik Antara Masyarakat, Pemerintah Dan Swasta. JISPO: Jurnal Ilmu Sosial Dan Ilmu Politik, 7(2), 24-42.

Lestari, S. (2012). Psikologi keluarga: Penanaman nilai dan penanganan konflik dalam keluarga. Sri Lestari.

Lubis, L. T. (2017). Teachers guidance and counseling efforts in improving student learning creativity in smk negeri 1 batang angkola. Ristekdik: Jurnal Bimbingan Dan Konseling, 2(2).

Tarigan, A. A. B., \& Dumayanti, I. S. (2018). Perancangan perangkat lunak pengenalan kebudayaan batak berbasis android. Majalah ilmiah methoda, 8(1), 69-79.

Yusuf, A. M. (2010). Metodologi Penelitian: Dasar-dasar penyelidikan ilmiah. Padang: UNP Pres, $23-24$. 